\title{
Novel APC gene mutations associated with protein alteration in diffuse type gastric cancer
}

Souvik Ghatak', Payel Chakraborty', Sandeep Roy Sarkar², Biswajit Chowdhury², Arup Bhaumik² and Nachimuthu Senthil Kumar ${ }^{1 *}$

\begin{abstract}
Background: The role of adenomatous polyposis coli (APC) gene in mitosis might be critical for regulation of genomic stability and chromosome segregation. APC gene mutations have been associated to have a role in colon cancer and since gastric and colon tumors share some common genetic lesions, it is relevant to investigate the role of APC tumor suppressor gene in gastric cancer.
\end{abstract}

Methods: We investigated for somatic mutations in the Exons 14 and 15 of APC gene from 40 diffuse type gastric cancersamples. Rabbit polyclonal anti-APC antibody was used, which detects the wild-type APC protein and was recommended for detection of the respective protein in human tissues. Cell cycle analysis was done from tumor and adjacent normal tissue.

Results: APC immunoreactivity showed positive expression of the protein in stages I, II, III and negative expression in Stages III and IV. Two novel deleterious variations ( $.127576 \mathrm{C}>\mathrm{A}, \mathrm{g} .127583 \mathrm{C}>\mathrm{T}$ ) in exon 14 sequence were found to generate stop codon $\left(\mathrm{Y}_{622^{*}}\right.$ and $\left.\mathrm{Q} 625^{*}\right)$ in the tumor samples. Due to the generation of stop codon, the APC protein might be truncated and all the regulatory features could be lost which has led to the down-regulation of protein expression. Our results indicate that aneuploidy might occurdue to the codon 622 and 625 APC-driven gastric tumorigenesis, in agreement with our cell cycle analysis. The APC gene function in mitosis and chromosomal stability might be lost and G1 might be arrested with high quantity of DNA in the $S$ phase. Six missense somatic mutations in tumor samples were detected in exon 15 A-B, twoof which showed pathological and disease causing effects based on SIFT, Polyphen2 and SNPs \& GO score and were not previously reported in the literature or the public mutation databases.

Conclusion: The two novel pathological somatic mutations (g.127576C > A, g.127583C > T) in exon 14 might be altering the protein expression leading to development of gastric cancer in the study population. Our study showed that mutations in the APC gene alter the protein expression and cell cycle regulation in diffuse type gastric adenocarcinoma.

Keywords: Adenomatous polyposis coli (APC), Gastric adenocarcinomas, Immunoreactivity, Mutation, Cell cycle

\footnotetext{
*Correspondence: nskmzu@gmail.com

'Department of Biotechnology, Mizoram University, Aizawl 796004, Mizoram,

India

Full list of author information is available at the end of the article
} International License (http://creativecommons.org/licenses/by/4.0/), which permits unrestricted use, distribution, and reproduction in any medium, provided you give appropriate credit to the original author(s) and the source, provide a link to the Creative Commons license, and indicate if changes were made. The Creative Commons Public Domain Dedication waiver (http://creativecommons.org/publicdomain/zero/1.0/) applies to the data made available in this article, unless otherwise stated. 


\section{Background}

Gastric cancer is one of the most common cancer worldwide and there are more than 100 new cases per year in Tripura, Northeast India with a 5-year survival rate $<10 \%$ [1]. A number of genetic abnormalities have been identified in gastric cancer, including mutations in tumor suppressor gene [2].However, the abnormalities individually exhibit frequencies of less than $50 \%$ in gastric tumors, and are variable depending on the population and number of the samples analysed.

The human APC (adenomatous polyposis coli) gene is a tumor suppressor gene located on the long (q) arm of chromosome 5 and it encodes a protein of $312 \mathrm{kDa}$ with 2843 amino acids. Inactivation of the APC geneis thought to be an initiating event for carcinogenesis [3]. Germline mutations of the APC gene are responsible for familial adenomatous polyposis (FAP) $[4,5]$. About 700 mutations in the APC gene have been identified and most of these mutations lead to the production of short and abnormalprotein which cannot suppress the cellular overgrowth,leading to the formation of polyps and become cancerous [6]. The APC gene inhibits the members of Wnt signalling pathway that promotes $\beta$-catenin expression as a stimulator of cell division within the intestinal crypts [7]. A functioning APC protein is thus vital in maintaining low levels of cytosolic $\beta$-catenin, thereby preventing excessive cell proliferation [8]. APC controls metaphase-anaphase transition and mitotic exit and regulates G1 phase [9, 10]. Over-expression of APC in fibroblasts and colon cancer cell lines leads to arrest of G1 phase in the cell cycle $[11,12]$. Role of APC in mitosis is critical for regulation of genomic stability and chromosome segregation [13]. Somatic mutations in the APC gene have been described in several tumour types such as pancreatic cancer [14], oral squamous-cell carcinoma [15] and oesophageal cancer [16]. APC mutations have been reported in gastric adenomas $[17,18]$ and in differentiated and signet-ring cell carcinomas [19]. Furthermore, frequent loss of heterozygosity on chromosome $5 \mathrm{q}$ has been detected in gastric carcinomas, particularly in well-differentiated type [20].Moreover, some differentiated types of gastric carcinoma are thought to originate from the intestinal metaplastic regions in gastric mucosa [21].

Since gastric and colon tumors share some common genetic lesions [22], it is relevant to investigate the role of APC tumor suppressor gene in the case of diffuse type gastric cancerwhich is not well characterized. Exons 14 and 15 are the most frequently mutated region for colorectal and gastric cancer as well as patients with familial adenomatous polyposis [23]. To clarify the role of APC gene mutations in the development of diffuse type gastric adenocarcinoma, we have investigated the mutations in the exons 14 and 15 of APC gene in a North East Indian population.

\section{Methods}

\section{Subjects}

The study design and data collection methods have been described in detail previously [24]. For this study, a total of 62 gastric cancer (GC) patients with or without a family history of cancer (median age 58 years; range 3779) who received treatment between September 2012 and February 2014 at Agartala Govt. Medical College, Tripura,Northeast India and 40 healthy volunteers (median age 52 years; range 31-73) were recruited. Individuals less than age 45 were classified as younger and those age 45 and older were classified as older. From the 62 samples, 40 diffuse type gastric tumor samples were selected and the patients with gastric neoplasms other than adenocarcinoma (MALT lymphoma, stromal or carcinoid tumors), secondary or recurrent GC, previous history of other malignancies or refusal to participate were excluded. The healthy control samples wereage and sex adjusted, and selected from same ethnic group, free of any other chronic diseases, not having any record of gastritis and not pre-treated for any other type of cancer. The tumour and adjacent normal tissue of the patients were grossed properly by a trained histopathology technician followed by preparation of paraffin block. Histologic assessment of tumor type and grade were performed routinely on 4 to $5 \mu \mathrm{m}$ thick hematoxyline \& eosin stained sections of formalin-fixed paraffinembedded tumors according to the criteria outlined in the World Health Organization Classification of Tumors. After staining, the cytopathological data was obtained from microscopic observationsto confirm that all the adjacent normal tissues were devoid of tumor cells. The blood samples were collected by an experienced laboratory technician using vacu-puncture procedure. The peripheral blood samples of the patients were kept in EDTA rinsed microcentrifuge tubes and $50 \mu \mathrm{l}$ of blood samples were processed for DNA isolation. Medical charts were reviewed to obtain information on cancer treatment, clinical stage, previous disease history and weight history. All participants gave written informed consent to the study protocol which was approved by the Ethical Committee of the Civil Hospital, Mizoram and Mizoram University, India (B.12018/1/13-CH(A)/IEC).The study protocol was also approved by the Institutional Review Board of all institutes involved in the study.

\section{Immunohistochemical analysis}

For the immunohistochemical study, 4- $\mu \mathrm{m}$ histological fragments were obtainedfrom the tumor tissue and adjacent normal tissue of the cases and placed on glass slides pre-treated with poly L-lysine (Sigma Chemical Co, MO, USA). Initially, histological slides were placed in an oven at $60{ }^{\circ} \mathrm{C}$ for 24 hours to obtain better tissue adhesion and deparaffinization. Deparaffinization was performed 
in three xylene baths at room temperature for $15 \mathrm{~min}$ and placed in three baths of absolute ethanol baths for $1 \mathrm{~min}$ each. The slides were washed in running water for $5 \mathrm{~min}$ and submitted to heat induced antigen recovery by steam in a $10 \mathrm{mM}$ citrate buffer solution with $\mathrm{pH} 6.0$ for $30 \mathrm{~min}$. After cooling for $20 \mathrm{~min}$ at room temperature, the slides were washed in running water for $5 \mathrm{~min}$ and endogenous peroxidase blocking was performed using a hydrogen peroxide solution at $3 \%$ in four baths of $5 \mathrm{~min}$ each. The slides were again washed in running water for $5 \mathrm{~min}$ and then washed with phosphate buffered saline (PBS) (pH 7.2-7.6) for $5 \mathrm{~min}$.

Rabbit polyclonal anti-APC antibody(ab52223) (Abcam, Japan) was used, which detects the wild-type APC protein and is recommended for detection of the respective protein in human tissue. Incubation was carried out at aconcentration of $1: 100$ in a humidified chamber at $4{ }^{\circ} \mathrm{C}$ for at least 16-18 hours (overnight). Subsequently, after three washes in PBS at pH 7.2 - 7.6, the incubation was performed with the streptavidin-biotin peroxidase kit (LSAB, DakoCytomation, CA, USA) in a humidified chamber at room temperature for $30 \mathrm{~min}$. This step was followed by washes with $\mathrm{PBS}$ at $\mathrm{pH} 7.2-7.6$ and development with liquid DAB (Sigma Chemical Co, MO, USA) at room temperature for $5 \mathrm{~min}$. After washing in running water for 3 min, counter-staining was performed with Harris hematoxylin for $1 \mathrm{~min}$. The sections were dehydrated in three baths with absolute ethanol and three baths of xylene and then mounted using cover slips with Entellan resin (Sigma Chemical Co., MO, USA) for analysis by optical microscopy. As positive control, slides with histological sections previously demonstrated as being positive for these antibodies were used. A similar slide was used as a negative control, subtracting the primary antibody from the reaction [25]. Staining was recorded as either present or absent. Presence of staining was not rated according to the intensity of staining. Extent of staining was graded as: $0,0-10 \%$ of cells positive; $1,10-50 \%$ of cells positive; 2 , greater than $50 \%$ of cells positive for APC. Staining was considered positive, if the extent of staining was graded as 2. Staining was considered reduced, if the extent was graded as 1 and 0 .

\section{DNA extraction from the blood sample}

The lymphocytes from patients' blood and unaffected control blood were separated by lysing the RBCs using a hypotonic buffer (ammonium bicarbonate and ammonium chloride, Hi-media) with minimal lysing effect on lymphocytes. Three volumes of RBC lysis buffer were added to the blood sample, mixed by vortexing and inverting thoroughly for $5 \mathrm{~min}$ and centrifuged (Eppendorf $5415 \mathrm{R}$, Germany) at 2,000 $\times \mathrm{g}$ for $10 \mathrm{~min}$. The lymphocytes were used for DNA extraction by modified protocol of Ghatak et al. [26].

\section{DNA extraction from the tissue samples}

Deparaffinization was carried out by adding $1 \mathrm{ml}$ of xylene to the tumor and adjacent normal tissue section in each microfuge tube, followed by vigorous vortexing for $10 \mathrm{mins}$. and centrifuged at $12000 \mathrm{rpm}$ for $10 \mathrm{mins}$. The supernatant was discarded and the deparaffinization steps were repeated once again, followed by rehydration through subsequent washings with 100\%, 90 and $70 \%$ absolute ethanol diluted in RNase free DEPC treated water, respectively. The deparaffinised tumor and adjusted normal tissue from the cases was used for the DNA extraction by the modified protocol of Ghatak et al. [27].

\section{PCR amplification of exons 14 and $15 A B$ of APC gene}

PCR was performed with the DNA from tumor, adjacent normal tissue, patient's blood and unaffected control blood samples. The APC gene exon 14 was amplified by PCR using primers Exon14-F (5' - ACATAGAAGTTAAT GAGAGAC -3') and Exon14-R (5'- TTGCTTACAAT TAGGTCTTTTTGA G -3'). The primers were designed for known polymorphic sites by using the IDT primer quest software. Polymerase chain reaction (PCR) was carried out in $25 \mu \mathrm{l}$ total reaction volume, each containing $100 \mathrm{ng}$ of template DNA, $0.2 \mathrm{pM}$ of each primer, $2.5 \mu \mathrm{l}$ of 10X PCR buffer, $1.5 \mathrm{mM} \mathrm{MgCl}_{2}, 200 \mathrm{mMdNTPs}$, and $1 \mathrm{U}$ of Taq DNA polymerase (Fermentas, Germany). The reaction mixture was heated to $94{ }^{\circ} \mathrm{C}$ for 5 minutes, followed by 30 cycles each consisting of $40 \mathrm{sec}$ denaturation at $94{ }^{\circ} \mathrm{C}, 40 \mathrm{sec}$ annealing at $54{ }^{\circ} \mathrm{C}, 1 \mathrm{~min}$ of extension at $72{ }^{\circ} \mathrm{C}$ and a final $5 \mathrm{~min}$ extension at $72{ }^{\circ} \mathrm{C}$. The APC exon 15A-B region was amplified by using Exon 15A-BF (5'- GGCAAGACCCAAACACATAATAG-3') and 15ABR (5'- GGAGATTTCGCTCCTGAAGAA -3'). The polymerase chain reaction (PCR) was carried out in $25 \mu$ total reaction volume, each containing $100 \mathrm{ng}$ of template DNA, $0.2 \mathrm{pM}$ of each primer, $2.5 \mu \mathrm{l}$ of $10 \mathrm{X}$ PCR buffer, $1.5 \mathrm{mM} \mathrm{MgCl} 2,200 \mathrm{mMdNTPs}$, and 1 unit of Taq DNA polymerase. The reaction mixture was heated to $94{ }^{\circ} \mathrm{C}$ for 5 minutes, followed by 35 cycles each consisting of $30 \mathrm{sec}$ denaturation at $94{ }^{\circ} \mathrm{C}, 30 \mathrm{sec}$ annealing at $59{ }^{\circ} \mathrm{C}, 1 \mathrm{~min}$ and $30 \mathrm{sec}$ of extension at $72{ }^{\circ} \mathrm{C}$ and a final $7 \mathrm{~min}$ extension at $72{ }^{\circ} \mathrm{C}$. The PCR amplification products $(10 \mu \mathrm{l})$ was subjected to electrophoresis in a $1.2 \%$ agarose gel in $1 \mathrm{X}$ TAE buffer at $80 \mathrm{~V}$ for $30 \mathrm{~min}$, stained with $(0.5 \mathrm{ug} / \mathrm{ml})$ Ethidium Bromide and images were obtained in GBOX gel documentation system (UK). PCR products were purified with a Qiagen gel extraction kit (Qiaquick columns; Qiagen, Chatsworth, CA) and stored at $-20{ }^{\circ} \mathrm{C}$ until sequenced using ABI 3500 Genetic Analyzer (Singapore) in Department of Biotechnology, Mizoram University, India.

\section{Cell cycle estimation}

$0.1 \mathrm{~g}$ of grossly gastric tumor and adjacent normal gastric mucosa tissue from the caseswere used for cell 
cycle analysis. Cells were harvested by mechanical dis-aggregation and fine-needle aspiration. Two separate aliquots of $6 \times 10^{6}$ tumor cells were prepared for each sample. Pellets were incubated with $250 \mathrm{~mL}$ of $0.1 \%$ RNAse (Sigma, St Louis, MO, USA) and $50 \mathrm{mg} / \mathrm{mL}$ Propidium iodide (presence of Sodium citrate and TritonX-100) for $30 \mathrm{~min}$ at $37^{\circ} \mathrm{C}$ and flow cytometric analysis was performed by Facs Canto and DIVA software (BD, Germany). Four distinct phases could be recognized in a proliferating cell population: the G1, S- (DNA synthesis phase), G2- and M-phase (mitosis). G2- and M-phase could not be discriminated because of the presence of identical DNA content [28]. The data obtained was analyzed using the ModFit LT software (DNA Modeling System) version 2.0 (Verity Software House, Inc.) and single parameter histograms were obtained.

\section{Single-strand conformation polymorphism (SSCP) analysis} The 5' half of exon 15 (codons 654- 1700) of APC gene was amplified using primer set (15A-B). An aliquot of $0.75 \mu \mathrm{l}$ of each PCR product from tumor and adjacent normal gastric mucosa tissue were diluted with an equal volume of water and mixed with $1.5 \mu 1$ of $95 \%$ formamide. This mixture was denatured at $95{ }^{\circ} \mathrm{C}$ for $5 \mathrm{~min}$, cooled on ice and $2 \mu \mathrm{l}$ was used for loading on SSCP gel (8\% non-denaturing polyacrylamide gels). SSCP Gels were pre-run at $400 \mathrm{~V}, 20 \mathrm{~mA}, 2 \mathrm{~W}$, for 10 or 50 volthours (Vh). Electrophoresis was performed at $400 \mathrm{~V}$, $20 \mathrm{~mA}, 2 \mathrm{~W}$, for 200-300 Vh. Electrophoresis was carried out at either $4,10,15$ or $20^{\circ} \mathrm{C}$ depending on the optimal temperature for a given PCR fragment [29]. The gels were ethidium bromide stained, and gel documented using Syngen-G-BOX (USA).

\section{Sequence analysis}

The samples exhibiting polymorphism and instability after SSCP analysis was taken for further sequencing and mutation analysis. All PCR products from the tumor, adjacent normal tissue, blood and unaffected control blood were sequenced from opposite directions to ensure reading accuracy. Sequences and chromatograms obtained were examined by chromas software version 2.13, DNA baser and align by BLAST [www.ncbi.nlm.nih.gov/blast]. The APC exons 14 and 15 were checked from Gene card database [HGNC - 583, Entrez Gene - 324, Ensembl - ENSG00000134982, OMIM - 611731, UniProtKB - P25054]. The sequences of tumor, adjacent normal was compared and sequence variation in tumor tissues from adjacent normal was recorded as somatic mutations. Further, it was confirmed that the sequence of patient's adjacent normal, blood and healthy control blood samples are 100\% identical. All the sequences containing the mutation were evaluated for their potential pathogenicity using the following algorithms: DNA baser version 3.5.4.2, Codon Code aligner version V.4.2.2, Mutation taster [www.mutationtaster.org/], PolyPhen-2 [http://genetics.bwh.harvard.edu/pph2/index.shtml.], SIFT [http://sift.jcvi.org], Mutation Assessor [http://mutationas sessor.org/]. The MEGA Align algorithm was used at two depths of alignment [Cancer to Normal and Normal to database sequences]. The results of PolyPhen-2 was retrieved from the original webpage [version 2.2.2] but also from version 2.0.22 run by PON-P and version 1 run by Condel, which use them for weighted average scores. Circos plot [30] was generated to visualize the mutations in exons $14-15$, protein expression and their association with gastric tumor stages and ploidy levels based on the observed data. This cross representation between mutations, APC protein expression and ploidy level explains the consequences of altered cell cycle regulation.

\section{Reconfirmation of mutations by restriction digestion}

Codon $622-625$ mutations in exons 14 alter the recognition site of restriction enzyme. The specific mutation detected together with restriction enzyme used and size of fragments expected after digestion of PCR products are given in Table 1. Digestion products were analysed by electrophoresis in $8 \%$ polyacrylamide gels which were stained with ethidium bromide and documented under UV light. Restriction digestion of PCR products was performed with the DNA from tumor, adjacent normal tissue and unaffected control blood samples.

\section{Statistical analysis}

Chi-square and Fisher's exact tests were used to assess the association ofAPC protein expression and cell cycle distribution with APC gene mutation status in relation to the stage of gastric cancer. For all tests, a two-sided $P$-value $<0.05$ was considered statistically significant. All analyses were performed using R statistical package ver3.3.0 [31].

\section{Results}

Gastric cancer was more prevalent in males (55\%) in the Tripura population. The median age in the younger age group was 36 years (range16-45), and this group contained a lesser proportion of patients $(35 \%)$ than the older age group (65\%) (Table 2). The most common symptoms were abdominal pain followed by weight loss and vomiting in the case of older age patient group. Most of the gastric cancer patients were operated with stage II tumor. The symptoms at recruitment in both groups are shown in Table 2.

The tumor samples used in the present study were diffuse type gastric adenocarcinoma as confirmed after $\mathrm{H} \& \mathrm{E}$ staining. Our data showed that $47.5 \%$ samples were in stage II, $32.5 \%$ in stage III and $20 \%$ in stage IV. In the normal control gastric mucosa, APC immunoreactivity was positive in all the 40 samples examined. Rabbit polyclonal 
Table 1 Somatic mutational profiling of APC gene exon 14 using PCR-RFLP

\begin{tabular}{|c|c|c|c|c|c|c|}
\hline Codon & Enzymes & Size of normal alleles (bp) & Mutation & Amino acids & Size of mutant alleles & Sample Frequency \\
\hline $622^{b}$ & Mspl & 189,163 & TAC $>>$ TAA & $Y>^{a}$ & 352 & $10 \%$ \\
\hline $625^{\mathrm{b}}$ & Mael & 266,86 & $\underline{C A G}>\underline{T A G}$ & $Q>{ }^{a}$ & $135,131,86$ & $5 \%$ \\
\hline
\end{tabular}

${ }^{\text {a }}$ represents stop codon

${ }^{b}$ represents Novel mutations (unreported in the database)

anti-APC antibody (ab52223) (Abcam, Japan) specificity was reported for endogenous levels of total APC protein and is expressed in a variety of tissues (http://www.abcam. com/apc-antibody-ab52223.html).Maximal APC immunoreactivity was present in the cytoplasm of the cell, but staining was not present in the mucus vacuoles. In $10 \%$ of the adenocarcinoma sample, APC immunoreactivity was completely absent despite the abundant expression of the protein in the adjacent normal mucosa. Four samples (10\%) were negative for APCprotein expression

Table 2 Clinicopathological features of gastric cancer patients (Stratified by age)

\begin{tabular}{|c|c|c|c|}
\hline Parameters & $\begin{array}{l}\text { Younger age group } \\
\text { (Age } \leq 45 \text { years) }\end{array}$ & $\begin{array}{l}\text { Older age group } \\
\text { (Age 46-79 years) }\end{array}$ & $P$-value \\
\hline \multicolumn{4}{|l|}{ Gender } \\
\hline Male & $06(15 \%)$ & $16(40 \%)$ & 0.326 \\
\hline Female & $08(20 \%)$ & $10(25 \%)$ & \\
\hline BMI (Mean \pm SD) & $21.4 \mathrm{~kg} / \mathrm{m}^{2} \pm 3.6$ & $22.1 \mathrm{~kg} / \mathrm{m}^{2} \pm 2.9$ & 0.058 \\
\hline $\begin{array}{l}\text { Tumor size }(\mathrm{cm}) \\
\text { (mean } \pm \mathrm{SD})\end{array}$ & $4.6 \pm 2.8$ & $4.9 \pm 3.1$ & 0.922 \\
\hline \multicolumn{4}{|l|}{ Tumor location } \\
\hline Upper & $08(20 \%)$ & $13(32.5 \%)$ & 0.869 \\
\hline Middle & $02(5 \%)$ & 05 (12.5\%) & \\
\hline Lower & $04(10 \%)$ & $06(15 \%)$ & \\
\hline Whole & 0 & $02(5 \%)$ & \\
\hline Type of gastrectomy & & & 0.186 \\
\hline Total & $10(25 \%)$ & $12(30 \%)$ & \\
\hline Subtotal & $04(10 \%)$ & $14(35 \%)$ & \\
\hline \multicolumn{4}{|l|}{ Stage } \\
\hline Stage I & 0 & 0 & \\
\hline Stage ॥ & 7 (17.5\%) & $12(30 \%)$ & 0.828 \\
\hline Stage III & $5(12.5 \%)$ & $8(20 \%)$ & \\
\hline Stage IV & $2(5 \%)$ & $6(15 \%)$ & \\
\hline Abdominal pain & $9(22.5 \%)$ & $16(40 \%)$ & 0.161 \\
\hline Weight loss & $5(12.5 \%)$ & $12(30 \%)$ & 0.05 \\
\hline Hemorrhage & 7 (17.5\%) & $3(7.5 \%)$ & 0.205 \\
\hline Dysphagia & $6(15 \%)$ & $5(12.5 \%)$ & 0.76 \\
\hline Early satiety & $3(7.5 \%)$ & $3(7.5 \%)$ & 1.00 \\
\hline Vomiting & $4(10 \%)$ & $12(30 \%)$ & 0.045 \\
\hline $\begin{array}{l}\text { Increased } \\
\text { Abdominal girth }\end{array}$ & $1(2.5 \%)$ & 0 & 0.317 \\
\hline
\end{tabular}

Values in parenthesis indicates percentage of that sample represented from the total number of studied samples in adenocarcinoma and 36 (90\%) werepositive (Table 3, Fig. 1).In gastric tumour Stage III, $7.5 \%$ of the samples showed negative protein expression.After performing the Fisher exact test, the APC expression was not significantlycorrelated with the Stages of gastric cancer $(p=0.077)$.APC immunoreactivity showedpositive expression of the protein in the stage I $(47.5 \%)$, stage II (25\%) and stage III (17.5\%) gastric adenocarcinoma and Stage III (7.5\%) and stage IV (2.5\%) showed negative expression of the protein.

We analysed the complete 352 bp coding region of exon 14 in the APC gene and found two novel deleterious sequence variations (g.127576C $>$ A, g.127583C $>$ T) changing the codons 622 and 625 to stop codons (Y622* and Q625*) in 10\% of tumor samples. But, thesesomatic mutations were not observed in adjacent normal tissues and blood samples of patients as well as in healthy control blood samples (Table 1, Figs. 2 and 3). The mutation was reconfirmed at codons 622 and 625 by performing restriction digestion with $M s p I$ and $M s a I$ (Additional file 1: Figure S1A). The wild type 622 codon (TAC) produced two digested products (189 bp and $163 \mathrm{bp}$ ), whereas mutant type codon (TAA) showed an uncut 352 bp band after MspI digestion. And, the 625 wild type codon (CAG) produced two digested products (266 bp and $86 \mathrm{bp}$ ), whereas mutant type codon (TAG) showed three distinct digested band (135 bp, $131 \mathrm{bp}, 86 \mathrm{bp}$ ) in the polyacrylamide gel.

Samples containing mutations in codon 622 and codon 625 ofexon 14 showed abnormal cell cycle stages and indicated that aneuploidy occurs due to Apc-driven gastric tumorigenesis. Samples with well differentiated diffuse type gastric adenocarcinoma showed a nonsense mutation from TAC (Y) to TAA (stop codon) at codon 622 and

Table 3 Immunohistochemical staining of APC protein in different gastric cancer stages

\begin{tabular}{lll}
\hline Tissue Type & \multicolumn{2}{l}{ APC immunohistochemistry } \\
\cline { 2 - 3 } & Positive & Negative \\
\hline Adjacent Normal cell & $40(100 \%)$ & 0 \\
Tumor cell & \\
Stage II & $19(47.5 \%)$ & 0 \\
Stage III & $10(25 \%)$ & $3(7.5 \%)$ \\
Stage IV & $7(17.5 \%)$ & $1(2.5 \%)$ \\
\hline
\end{tabular}

$P$ value $=0.07$

Values in parenthesis indicates percentage of that sample represented from the total number of samples 


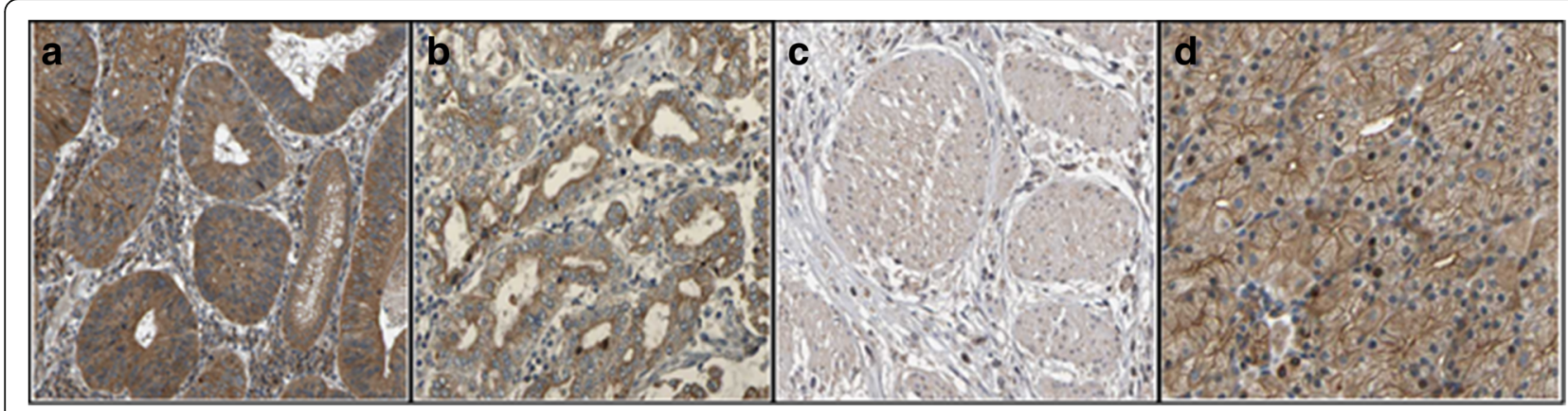

Fig. 1 Microscopic view of well differentiated adenocarcinoma of gastric tumor cells. a Positive high immunoexpression of anti-APC antibody in cancer cell (b) Positive moderate immunoexpression of anti-APC antibody in cancer cell (c) Negative immunoexpression of anti APC antibody in cancer cell (d) Positive moderate immunoexpression of anti-APC antibody in adjacent normal cell (from negative immunoexpression cancer cell), represented by the brownish colour in the cytoplasm and membrane

samples with poorly differentiated diffuse type gastric adenocarcinoma had a change from CAG (tryptophan) to TAG (stop codon) at codon 625 (Fig. 2) resulting in a truncated gene product. The tumor samples with Y622* and Q625* mutations exhibited G1 phase arrest with high $S$ phase DNA ( $p$ value $=0.071$ ) leading to loss of the role of APC in mitosis and chromosome stability [32].Most of the gastric cancer samples showed diploidy, except in samples containing 622 and 625 codon change where aneuploidy resulted in less DNA content in G2/M phase and high DNA content in S phase (Fig. 4).

The 936 bp coding region of exon 15 in the APC gene and somatic variants were detected in the gastric cancersamples (Table 4). We observed a change of exon 15 A-B region by SSCP (Additional file 1: Figure S1B). These tumour samples showedan instability banding pattern,unlike thematched adjacent normal tissue and blood of the patient's sample as well as the healthy control blood samples. Further, these samples were sequenced and six missense somatic mutations (g.131270A > G, AA1058D > G; g.131346 T > G, AA1083D > E; g.131420A > G, AA1108N > S; g.131836G > A,
AA1247A > T; g.132017 T > A, AA1307I > K; g.132046G > C, AA1317E $>$ Q) were detected randomly in a total of $40 \%$ of tumor samples which causes abnormal protein products(Table 4, Fig. 3, Additional file 1: Figure S2). Among the six missense mutations, two $(1058 \mathrm{D}>\mathrm{G}$ and $1307 \mathrm{I}>\mathrm{K}$ ) were not previously reported in the literature or the public ensemble mutation databases. Both the mutations were pathological and disease causing based on SIFT, Polyphen2 and SNPs \& GO scores. Most of the exon 15 mutations were found in the compositional bias region of the APC protein.

Based on the Circos plot analysis, stage III and IV tumor samples were associated with the absence(negative) of APC protein expression, whereas Y622* and Q625* mutations were associated with stage II, III and IV tumor samples. Y622* mutated and negative APC protein expressing gastric tumor samples had a high concordance with aneuploid cells (Fig. 3). Fisher's exact test exhibited a significant statistical association of $\mathrm{Y}_{62} 2^{*}$ and A1247T mutations with negative APC protein expression $(P=0.0002 ; 0.005)$, whereas, a positive protein

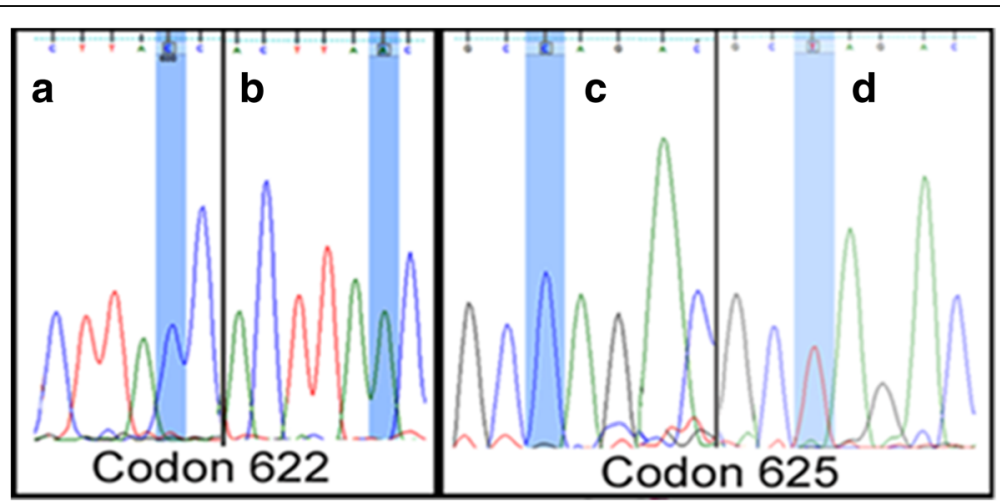

Fig. 2 Different Mutation in the exon 14 (g.127576C > A, g.127583C > T) of APC protein. a Wild type codon 622 (TAC) in adjacent normal sample, b Mutant type codon 622 (TAA) in tumor sample, c Wild type codon 625 (CAG) in adjacent normal sample, d Mutant type codon (TAG) in tumor sample 


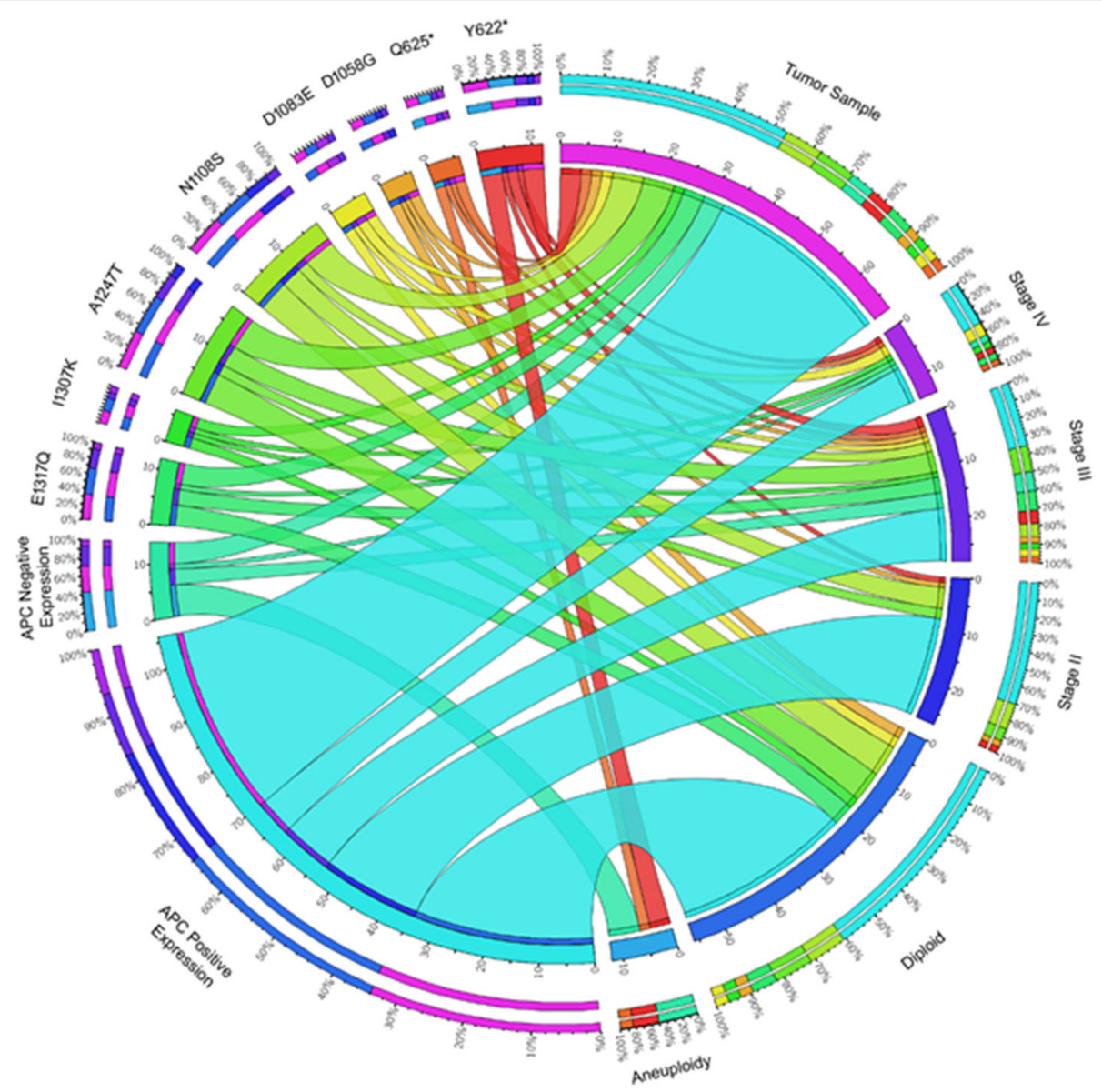

Fig. 3 Circos plot of representative APC mutation in gastric tumor sample and their association with cancer stages, cell cycle, and APC protein expression. The frequency of occurrence of different factors such as mutations, APC protein expression pattern, ploidy level and tumor stages is depicted in the outer ring. The inner ring of circos plot depicts the association between the mutations, APC protein expression pattern, ploidy level and tumor stage involved in gastric cancer. Each factor has been assigned a color. The arc originates from mutations and APC protein expression status and terminates at tumor staging and ploidy level to compare the association between the origin and terminating factors. The area of each colored ribbon depicts the frequency of the samples related with the particular mutations and APC protein expression
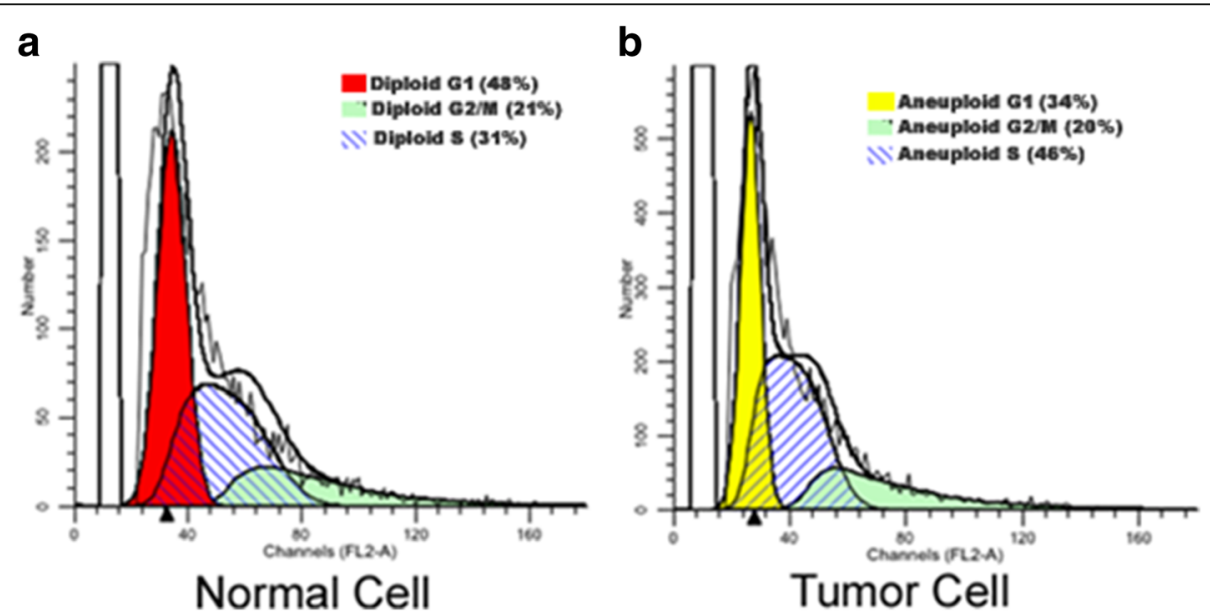

Fig. 4 Histogram of Cell cycle analysis of (a) adjacent control gastric cell and (b) Tumor gastric adenocarcinoma cell $(p$ value $=0.071)$ 


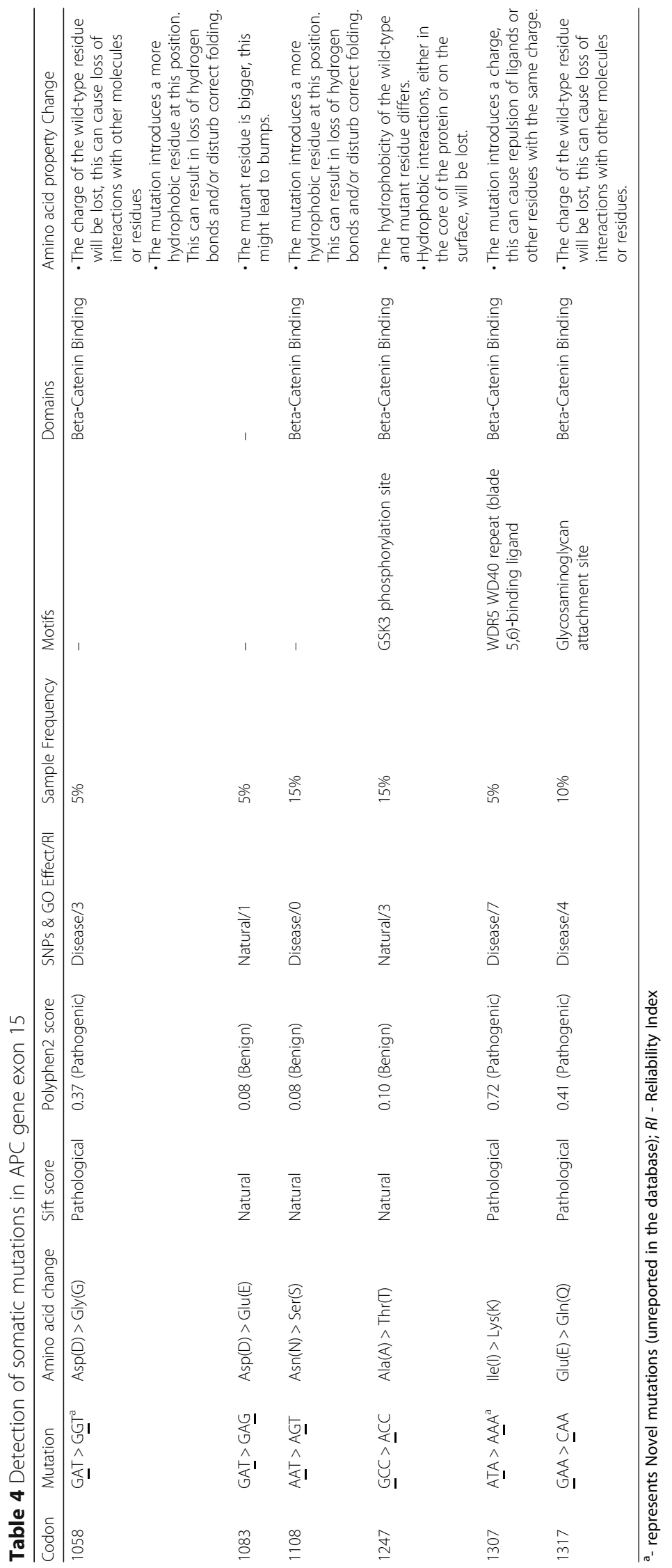


expression $(P=0.0003)$ was observed in association with N1108S mutation. The mutated region was responsible for down-regulation through a process mediated by direct ubiquitination which will affect the protein function and alter the cell cycle regulation.

\section{Discussion}

Mutations of APC gene has been shown to play an important role in colorectal tumorigenesis [33]. In the current study, we have found a significant relationship between the APC mutation, cell cycle regulation and protein expression indicating a positive role of the mutations in diffuse type gastric adenocarcinomas. We have found frequent pathogenic mutations at codon 622 of exon14 APC in gastric tumors that generates stop codon (Y622*). All the samples containing codon 622 mutation showed abnormal cell cycle regulation. All the samples containing 622 and 625 codon mutation coded for a truncated protein and resultant cells were aneuploid with high S phase. Tumor samples with codon 622,625 and 1307 mutations were strongly associated with the negative expression of the APC protein in cytoplasm as shown in immunohistochemistry analysis. Previous study showed that truncations in APC eliminate microtubule binding contributing to chromosome instability (the CIN phenotype) in colon cancer cells because they directly affect chromosome-spindle attachment [13]. Phosphorylation of APC by Bub kinases may be an important aspect of CIN phenotype, explaining why the loss of Bub1 kinase activity is a common feature of colon cancer cell lines [13]. Loss of APC function results in microtubule plusend attachment defects during mitosis and consequent chromosome misalignment and CIN [34]. Due to exon 14 mutation, APC protein might be truncated and the same phenomenon might occurin gastric cancer leading to aneuploidy and G1 phase arrest followed by high S phase in cell cycle for diffuse type gastric cancer. It is evident that the two mutations in exon 14 of APC gene were independent of each other and are responsible for loss of protein function based on our data analysis and from the APC Mutation Database.

Our results are in agreement with the finding that mutations of APC in sporadic cases have been detected in coding amino acids within a short range from 1058 to 1317, which exists inside exon 15 and is called the mutation cluster region (MCR) [35]. Mutations in exon 15 of APC gene were detected in $40 \%$ of gastric cancers and are similar to the previous studies [17]. Our results imply that APC plays a crucial role in gastric carcinogenesis as was observed in colorectal carcinogenesis [33]. The mutations detected were located in relatively small part of exon 15 . Since exon 15 is extremely large, covering codons 654 through 2843 (77\% of the whole coding region), it is probable that this exon encodes one of the important domains of the gene product. Alternatively, this region may be a hot spot of mutation for targeting by carcinogens. One particular missense variant, I1307K, is found in Tripura population, and carriers of this allele are at several fold higher risk of developing multiple gastric adenomas and colorectal cancer [36]. As the $11307 \mathrm{~K}$ variant consist of T-A substitution producing a poly (A) tract, it was assumed that the variant precipitated polymerization error during DNA replication, and thus indirectly predisposition to cancer [36]. E1317Q codes for a mutation in the MCR region of the APC gene at $\beta$-catenin binding site and this mutation acts like $\mathrm{I} 1307 \mathrm{~K}$, by a dominant negative effect on the APC/ $/$-catenin pathway, thus leading to adenoma [37]. E1317Q mutation has been detected in colorectal polyps or cancer like as in the case of the present study [38].

The antisera that react with the specific epitope of the APC protein were used for immuno-histochemical staining to demonstrate the protein expression in gastric tumors. The subcellular localization of the APC protein is reported to be predominantly cytoplasmic in normal tissues, though mammary epithelium has been reported to show equal distribution of cytoplasmic and nuclear APC [25].In the present study, APC protein was detected more in the cytoplasmic staining in gastric tumors when compared to normal tissues. An antibody for the C-terminal region of the APC protein that detects only full-length or wild-type APC protein was used in the present study. The mutated APC protein loses its binding site in the $\beta$ catenin destruction complex resulting in low expression of APC in the cytoplasm and nucleus, which ultimately results in decreased membrane expression [39].The gastric cancer tumor in stage III and stage IV showed negative expression of the protein in cytoplasm and nucleus.

Sequencing analysis confirmed that the mutations in exons 14 and 15 of APC gene resulted in truncation of the gene products or in an amino acid change. APC gene encodes a large protein with multiple cellular functions and mutations in this gene lead to alterations in signal transduction, differentiation, intercellular adhesion, cytoskeletal stabilization, cell cycle and apoptosis [40, 41]. Truncating mutations in exons 14 and 15 were strongly associated with gastric and colorectal cancer [42]. A wealth of data shows that almost all colorectal tumors with APC mutations lose the SAMP (connexion/ actin/ $\beta$-catenin binding) repeats and all,or otherwise one or two of the seven $\beta$-catenin binding/degradation sites. Colorectal tumour retains a truncated APC protein to control the transcriptional activity of $\beta$-catenin and avoids it to reach too high levels, which is detrimental for tumour growth, in agreement with the "just right signalling" model [43]. The truncated APC can influence the transcriptional activity of $\beta$-catenin by at least two different mechanisms: a stimulation of the transcriptional 
activity of $\beta$-catenin upon APC downregulation without any obvious increase of the $\beta$-catenin level [44] and alternatively, truncated APC might be required for tumour development independently of its control over the transcriptional activity of $\beta$-catenin as previously discussed [45]. The APC protein might be truncated and all the regulatory features might be lost, especially the feature responsible for down-regulation through a process mediated by direct ubiquitination.

In the present study, eight APC mutations in exons 14 and 15 were all detected in diffuse type gastric cancer. The codon 622 and 625 mutations are significantly associated with cell cycle abnormality. This result indicates that APC gene is mutational target for gastric cancer tumor cells and supports the hypothesis that APC mutation-positive tumors may identify an alternative pathway which is probably different from the normal pathway. Our study showed that mutations in APC can contribute to development of diffuse type gastric adenocarcinomas by altering the APC protein expression and cell cycle regulation and additional genetic changes could account for the differences in pathology.

\section{Conclusion}

The present study suggests the implication of novel APC gene alterations in gastric cancer related with cell cycle abnormalities and APC protein expression in diffuse type gastric cancer. Our findings need to be confirmed by a larger cohort study, however, we reduced the risk of falsepositive diagnosis of patients with other diseases by enrolling the patients with only diffuse type gastric cancer.

\section{Additional file}

Additional file 1: Figure S1. (A) PCR-RFLP of APC gene Exon 14 (M - 100 bp marker; S1, S2 - Normal alleles; S3, S4 - Mutant alleles); (B) SSCP analysis of APC gene exon 15A.b. (1, 2 - Healthy Control; 3,4,5,6 - Tumour tissues; 7,8 - Matched tissues). Figure S2. Exon 15 non-synonymous mutation positions in the APC protein (DOCX $856 \mathrm{~kb}$ ).

\section{Abbreviations}

ul: Microliter; $\mu \mathrm{m}$ : Micro meter; APC: Adenomatous Polyposis Coli; DNA: Deoxyribonucleic acid; H: Hour; kDa: Kilo Dalton; MCR: Mutation cluster region; Min: Minute; mM: Mile Moller; PBS: Phosphate Buffer Saline; PCR: Polymerase chain reaction; RNA: Ribonucleic acid; SNP: Single Nucleotide Polymorphism; SSCP: Single stranded conformation polymorphism; Vh: Volt-hours

\section{Acknowledgements}

The authors also thank the Department of Pathology, Agartala Gov. Medical College for the sample collection and DBT- infrastructural facility (BT/Med/ NE-SFC/2009 Dated: 24.09.2009) and Mizoram University DBT- Uexcel project (BT/551/NE/U-Excel/2014/43) for the sequencing facility.

\section{Funding}

The authors thank Department of Biotechnology, New Delhi, India for support in the form of Advanced level State Biotech Hub (BT/04/NE/2009 Dated: 29.08.2014) and Bioinformatics Infrastructural Facility (BT/BI/12/060/ 2012 (NERBIF-MUA), Mizoram University which provided all the essential facilities to carry out the work.

\section{Availability of data and materials}

Materials, data, code, and associated protocols are promptly available to readers without undue qualifications. There are no restrictions on the availability of materials, data and associated protocol. Study data and materials will be available in Department of Biotechnology, Mizoram University, Aizawl, Mizoram. All the nucleotide sequences are available in EMBL-EBI (GenBank accession codes: LT855206 - LT855224).

\section{Author's contributions}

Participated in research design: $A B$ and NSK. Conducted experiments: SG, PC, SRS and BC. Performed data analysis: SG, PC and SRS. Wrote or contributed to the writing of the manuscript: SG, AB and NSK. All authors read and approved the final manuscript.

\section{Publisher's Note}

Springer Nature remains neutral with regard to jurisdictional claims in published maps and institutional affiliations.

\section{Author details}

'Department of Biotechnology, Mizoram University, Aizawl 796004, Mizoram, India. ${ }^{2}$ Department of Pathology, Agartala Government Medical College, Tripura, India.

Received: 10 April 2017 Accepted: 24 May 2017

Published online: 02 June 2017

\section{References}

1. Gandhi AK, Rath GK. National cancer control and registration program in India. Indian J Med Paediatr Oncol. 2014;35:288-90.

2. Lee HS, Lee HK, Kim HS, Yang HK, Kim WH. Tumour suppressor gene expression correlates with gastric cancer prognosis. J Pathol. 2003; 200:39-46.

3. Powell SM, Zilz N, Beazer-Barclay Y, Bryan TM, Hamilton SR, Thibodeau SN, Vogelstein B, Kinzler KW. APC mutations occur early during colorectal tumorigenesis. Nature. 1992;359:235-7.

4. Nishisho I, Nakamura Y, Mivoshi Y, Miki Y, Ando H, Horii A. Mutations of chromosomes 5q21 genes in FAP and cokorctal cancer patients. Science. 1991;253:665-9.

5. Groden J, Thliveris A, Samovitz WS, Carlson MI, Gilbert L, Albertsen H, Joslyn G, Stevens J, Spirio L, Robertson M, Sargeant L, Krapcho K, Wolff E, Burt R, Hughes JP, Warrington J, McPherson J, Wasmuth J, Paslier DL, Abderrahim $H$, Cohen D, Leppert M, White R. Identification and characterization of the familial adenomatous polyposis coli gene. Cell. 1991;66:589-600.

6. Smith KJ, Johnson KA, Bryan TM, Hill DE, Markowitz S, Willson JKV, Paraskeva C, Petersenii GM, Hamilton SR, Vogelstein B, Kinzler KW. The APC gene product in normal and tumor cells. Proc Nat Acad Sci. 1993;90:2846-850.

7. Behrens J, Von-Kries JP, Kuhl M, Bruhn L, Wedlich D, Grosschedl R, Birchmeier W. Functional interaction of $\beta$-catenin with the transcription factor LEF-1. Nature. 1996;382:638-42.

8. Dumas YR, He X. Wnt signaling: What the X@\# is WTX! EMBO J. 2011; 30:1415-7.

9. Vodermaier HC. APC/C and SCF: controlling each other and the cell cycle. Curr Biol. 2004;14:R787-96.

10. Nakayama Kl, Nakayama K. Ubiquitin ligases: cell-cycle control and cancer. Nat Rev Cancer. 2006;6:369-81.

11. Ishidate T, Matsumine A, Toyoshima K, Akiyama T. The APC-hDLG complex negatively regulates cell cycle progression from the G0/G1 to $S$ phase. Oncogene. 2000;19:365-72.

12. Heinen CD, Goss KH, Cornelius JR, Babcock GF, Knudsen ES, Kowalik T, Groden J. The APC tumor suppressor controls entry into S-phase through its ability to regulate the cyclin D/RB pathway. Gastroenterol. 2002;123:751-63.

13. Kaplan KB, Burds AA, Swedlow JR, Bekir SS, Sorger PK, Nathke IS. A role for the Adenomatous Polyposis Coli protein in chromosome segregation. Nat Cell Biol. 2001;3:429-32.

14. Horii A, Nakatsuru S, Miyoshi Y, Ichii S, Nagase H, Ando H, Yanagisawa A, Tsuchiya E, Kato Y, Nakamura Y. Frequent somatic mutations of the APC gene in human pancreatic cancer. Cancer Res. 1992;52:6696-8.

15. Wang XL, Uzawa K, Imai FL, Tanzawa H. Localization of a novel TumorSuppressor gene associated with human oral cancer on chromosome 4q25. Oncogene. 1999;18:823-5. 
16. Rumpel CA, Powell SM, Moskaluk CA. Mapping of genetic deletions on the LongArm of chromosome 4 in human esophageal adenocarcinomas. Am J Path. 1999;154:1329-33.

17. Nakatsuru S, Yanagisawa A, Ichii S, Tahara E, Kato Y, Nakamura Y, Horii A Somatic mutation of the APC gene in gastric cancer: Frequent mutations in very well differentiated adenocarcinoma and signet-ring cell carcinoma. Hum Mol Genet. 1992;1:559-63.

18. Tamura G, Maesawa C, Suzuki Y, Ogasawara S, Terashima M, Saito K, Satodata R. Primary gastric carcinoma cells frequently lose heterozygosity at the APC and MCC genetic loci. Jpn J Cancer Res. 1993;84:1015-8.

19. Maesawa C, Tamura G, Suzuki Y, Ogasawara S, Sakata K, Kashiwaba M, Satodate R. The sequential accumulation of genetic alterations characteristic of the colorectal adenoma-carcinoma sequence does not occur between gastric adenoma and adenocarcinoma. J Pathol. 1995;176:249-8.

20. Sano T, Tsujino T, Yoshida K, Nakayama H, Haruma K, Ito H, Nakamura Y, Kajiyama G, Tahara E. Frequent loss of heterozygosity on chromosomes lq 5q, and 17p in human gastric carcinomas. Cancer Res. 1991;51:2926-31.

21. Jarvi $\mathrm{O}$, Lauren $\mathrm{P}$. On the role of heterotopies of the intestinal epithelium in the pathogenesis of gastric cancer. Acta pathol micobiol scand. 1951;29:26.

22. Uchino S, Noguchi M, Ochiai A, Saito T, Kobayashi M, Hirohashi S. p53 mutations in gastric cancer: a genetic model for carcinogenesis is common to gastric and colorectal cancer. Int J Cancer. 1993;54:759-64.

23. Liu Q, Li X, Ma H, Li S, Yang L. Three novel mutations of APC gene in Chinese patients with familial adenomatous polyposis. Tumir Biol. 2016;37:11421-7.

24. Ghatak S, Lallawmzuali D, Lalmawia, Sapkota R, Zothanpuia, Pautu JL, Muthukumaran RB, Senthil-Kumar N. Mitochondrial D-loop and Cytochrome Oxidase C subunit I polymorphisms among the breast cancer patients of Mizoram, Northeast India. Curr Genet. 2014;60(3):201-12.

25. Grace A, Butler D, Gallagher M, Al-Agha R, Xin Y, Leader M, Key E. APC gene expression in gastric carcinoma: an immunohistochemical study. Appl Immunohistochem Mol Morphol. 2002;10(3):221-4

26. Ghatak S, Muthukumaran RB, Senthil-Kumar N. A simple method of genomic DNA extraction from human samples for PCR-RFLP analysis. J Biomol Tech. 2013;24:224-31.

27. Ghatak S, Sanga Z, Pautu JL, Kumar NS. Coextraction and PCR based analysis of nucleic acids from formalin-fixed paraffin-embedded specimens. J Clin Lab Anal. 2014;DOI: 10.1002/jcla.21798.

28. Blanco R, Rengifo CE, Cedeño M, Frómeta M, Rengifo E. Flow cytometric measurement of aneuploid DNA content correlates with high S-phase fraction and poor prognosis in patients with Non-small-cell lung cancer. ISRN Biomarkers. 2013;2013:1-8.

29. Gayther SA, Warren W, Mazoyer S, Russell PA, Harrington PA, Chiano M, Seal S, Hamoudi R, Rensburg EJV, Dunning AM, Love R, Evans G, Easton D, Clayton D, Stratton MR, Ponder BAJ. Germline mutations of the BRCA1 gene in breast and ovarian cancer families provide evidence for a genotypephenotype correlation. Nat Genet. 1995;11:428-33.

30. Krzywinski M, Schein J, Birol I, Connors J, Gascoyne R, Horsman D, Jones SJ, Marra MA. Circos: an information aesthetic for comparative genomics. Genome Res. 2009;19:1639-45.

31. R Core Team. R: A language and environment for statistical computing. Vienna, Austria: R Foundation for Statistical Computing; 2016. URL https:// www.R-project.org/.

32. Caldwell CM, Kaplan KB. The role of APC in mitosis and in chromosome instability. Adv Exp Med Biol. 2009;656:51-64.

33. World Cancer Research Fund/American Institute for Cancer Research. The associations between food, nutrition and physical activity and the risk of stomach cancer and underlying mechanisms. Leeds, UK: University of Leeds; 2006.

34. Green RA, Kaplan KB. Chromosome instability in colorectal tumor cells is associated with defects in microtubule plus-end attachments caused by a dominant mutation in APC. J Cell Biol. 2003;163:949-61.

35. Miyoshi $Y$, Nagase $H$, Ando H, Nishisho I, Horii A, Aoki IST, Miki Y, Mori T, Nakamura Y. Somatic mutations of the APC gene in colorectal tumors: mutation cluster region in the APC gene. Hum Mol Gen. 1992;4:229-33.

36. Laken SJ, Petersen GM, Gruber SB, Oddoux C, Ostrer H, Giardiello FM, Hamilton SR, Hampel H, Markowitz A, Klimstra D, Jhanwar S, Winawer S, Offit K, Luce MC, Kinzler KW, Vogelstein B. Familial colorectal cancer in Ashkenazim due to a hypermutable tract in APC. Nat Genet. 1997;17:79-83.

37. Frayling IM, Beck NE, Ilyas M, Dove-Edwin I, Goodman P, Pack K, Bell JA, Williams CB, Hodgson SV, Thomas HJW, Talbot IC, Bodmer WF, Tomlinson IPM. The APC variants $11307 \mathrm{~K}$ and E1317Q are associated with colorectal tumors, but not always with a family history. Proc Natl Acad Sci. 1998;95:10722-7.
38. Popat S, Stone J, Coleman G, Marshall G, Peto J, Frayling I, Houlston R Prevalence of the APC E1317Q variant in colorectal cancer patients. Cancer Lett. 2000;149(1-2):203-6.

39. Luo L, Shen GQ, Stiffler KA, Wang QK, Pretlow TG, Pretlow T. Loss of the heterozygosity in human aberrant crypt foci (ACF), a putative precursor of colon cancer. Carcinogenesis. 2006;27:1153-9.

40. Zhang F, White RL, Neufeld KL. Phosphorylation near nuclear localization signal regulates nuclear import of adenomatous polyposis coli protein. Proc Natl Acad Sci. 2000;97:12577-82.

41. Fearnhead NS, Britton MP, Bodmer WF. The ABC of APC. Hum Mol Genet. 2001;10(7):721-33

42. Wang J, Wang X, Gong W, Mi B, Liu S, Jiang B. Increased expression of B-catenin, phosphorylated glycogen synthase kinase $3 B$, cyclin d1, and c-mycin laterally spreading colorectal tumors. J Histochem Cytochem. 2009:57:363-71.

43. Albuquerque C, Breukel C, Van-der LR, Fidalgo P, Lage P, Slors FJM, Leitão $C N$, Fodde $R$, Smits $R$. The 'just-right' signaling model: APC somatic mutations are selected based on a specific level of activation of the beta-catenin signaling cascade. Hum Mol Genet. 2002;11:1549-60.

44. Chandra SHV, Wacker I, Appelt UK, Behrens J, Schneikert J. A common role for various human truncated adenomatous polyposis coli isoforms in the control of beta-catenin activity and cell proliferation. PLOS ONE. 2012;7(4):e34479.

45. Schneikert J, Behrens J. The canonical Wnt signalling pathway and its APC partner in colon cancer development. Gut. 2007;56:417-25.

\section{Submit your next manuscript to BioMed Central and we will help you at every step:}

- We accept pre-submission inquiries

- Our selector tool helps you to find the most relevant journal

- We provide round the clock customer support

- Convenient online submission

- Thorough peer review

- Inclusion in PubMed and all major indexing services

- Maximum visibility for your research

Submit your manuscript at www.biomedcentral.com/submit

) Biomed Central 